\title{
Penentuan Zona Kerentanan Longsor Berdasarkan Karakteristik Geologi dan Alterasi Batuan
}

\author{
Anastasia Dewi Titisari*, Hitznaiti Zaidini' Khul Husna, Ilham Dharmawan Putra, \\ dan I Gde Budi Indrawan
}

\author{
Departemen Teknik Geologi, Fakultas Teknik, Universitas Gadjah Mada, Yogyakarta \\ adewititisari@ugm.ac.id
}

Submisi: 30 Mei 2018; Penerimaan: 22 Januari 2019

\section{Kata Tunci:}

alterasi argilik;

alterasi

propilitik;

Hargotirto;

kerentanan longsor.
Keywords: argillic alteration; Hargotirto; landslide susceptibility; prophyllitic alteration
ABSTRAK Longsor merupakan salah satu bencana yang sering terjadi di Indonesia. Kejadian longsor sangat dikontrol oleh kondisi geologi, terutama di daerah dengan batuan penyusun yang telah mengalami alterasi. Wilayah Desa Hargotirto, Kecamatan Kokap, Kabupaten Kulon Progo, DIY disusun oleh batuan yang telah mengalami alterasi sehingga banyak terjadi tanah longsor. Oleh karena itu, perlu dilakukan penentuan zona kerentanan longsor berdasarkan karakteristik geologi dan alterasi batuan di daerah tersebut sebagai salah satu upaya mitigasi bencana untuk mengurangi risiko bencana longsor. Penelitian tersebut dilakukan dengan metode pengumpulan data di lapangandata kemiringan lereng, kondisi geologi, dan penutup lahan — serta analisis laboratorium berupa analisis petrografi, analisis XRD (X-Ray Diffraction), dan analisis geokimia batuan menggunakan teknik ICP-AES (Inductively Coupled Plasma- Atomic Emission Spectroscopy). Data-data yang dikumpulkan kemudian digunakan sebagai parameter untuk menentukan zonasi longsor menggunakan metode Analytical Hierarchy Process (AHP). Hasil penelitian menunjukkan bahwa litologi penyusun daerah penelitian adalah andesit dan diorit porfiri dengan tipe alterasi batuan argilik dan propilitik yang intensitasnya dikategorikan sebagai alterasi rendah hingga sedang. Berdasarkan kondisi tersebut, terdapat empat tingkat kerentanan longsor, yaitu kerawanan sangat tinggi yang mendominasi sebesar 35\% daerah penelitian di bagian utara dan barat laut; tingkat kerawanan longsor tinggi sebesar $20 \%$ tersebar di bagian tengah; tingkat kerawanan sedang sebesar $20 \%$ terdistribusi di bagian tengah selatan; dan tingkat kerawanan rendah sebesar $25 \%$ tersebar di bagian selatan daerah penelitian. Oleh karena itu, penduduk yang bermukim di daerah yang termasuk dalam zona kerawanan longsor sangat tinggi dan tinggi disarankan untuk selalu waspada terhadap kemungkinan terjadinya longsor.

ABSTRACT Landslide is one of the most frequent disasters in Indonesia. The occurrence of landslides is heavily controlled by geological conditions especially in areas with composed by altered rocks. Hargotirto Village, Kokap District, Kulon Progo Regency, DIY is composed by altered rocks so that many landslides occur.It is necessary, thereforeto determine the landslide susceptibility zone based on the geological characteristics and rock alteration in the area as one of disaster mitigation efforts to reduce the risk of landslide disaster. The research method used is data collection in the field such as inclination data of slope, geological condition, and land cover; and laboratory analysis such as petrographic analysis, XRD (X-Ray Diffraction) analysis, and rock geochemical analysis using ICP-AES (Inductively Coupled Plasma - Atomic 
Emission Spectroscopy).The collected data are used as parameters for landslide zonation determination using Analytical Hierarchy Process (AHP) method.The results showed that the lithology of the research area is andesite and porphyry diorite with alteration type of argillic and propylitic alteration. Their intensity are categorized as low to moderate alteration.Based on these conditions can be categorized into4 levels of landslide susceptibility namely the very high landslide susceptibility that dominates 35\% of research areas in the north and northwest; the high landslide susceptibility of $20 \%$ spreads over the center of the study area; the moderate landslide susceptibility of $20 \%$ distributed in the center southernof the study area; and the low landslide susceptibility of $25 \%$ spread over the southern part of the study area.Therefore, residents who live in the area are advised to always be alert to the possibility of landslide because it is included in the zone of very high and high landslide susceptibility.

\section{PENDAHULUAN}

Longsor merupakan bencana yang cukup sering terjadi di Indonesia. BNPB (2017) menyebutkan bahwa tanah longsor merupakan bencana dengan jumlah kejadian terbanyak ketiga di Indonesia, yaitu sebanyak 4.339 kejadian dari tahun 1815 hingga 2017. Salah satu kabupaten yang sering mengalami kejadian longsor adalah Kabupaten Kulon Progo, Daerah Istimewa Yogyakarta. Salah satu faktor yang menyebabkan longsor di daerah Kulon Progo adalah faktor kondisi geologi, antara lain, kondisi kelerengan, struktur batuan, dan intensitas alterasi batuan. Studi tentang alterasi batuan di wilayah Kulon Progo pernah dilakukan oleh Harjanto (2010). Harjanto (2011) juga melakukan penelitian mengenai petrologi dan geokimia batuan volkanik di Daerah Kulon Progo yang data-datanya diperlukan untuk mendukung penelitian ini. Terdapat 22 desa dari 6 kecamatan di Kabupaten Kulon Progo yang masuk zona rawan longsor (BPBD DIY, 2017), termasuk Desa Hargotirto dan sekitarnya yang terletak di Kecamatan Kokap (Gambar1).

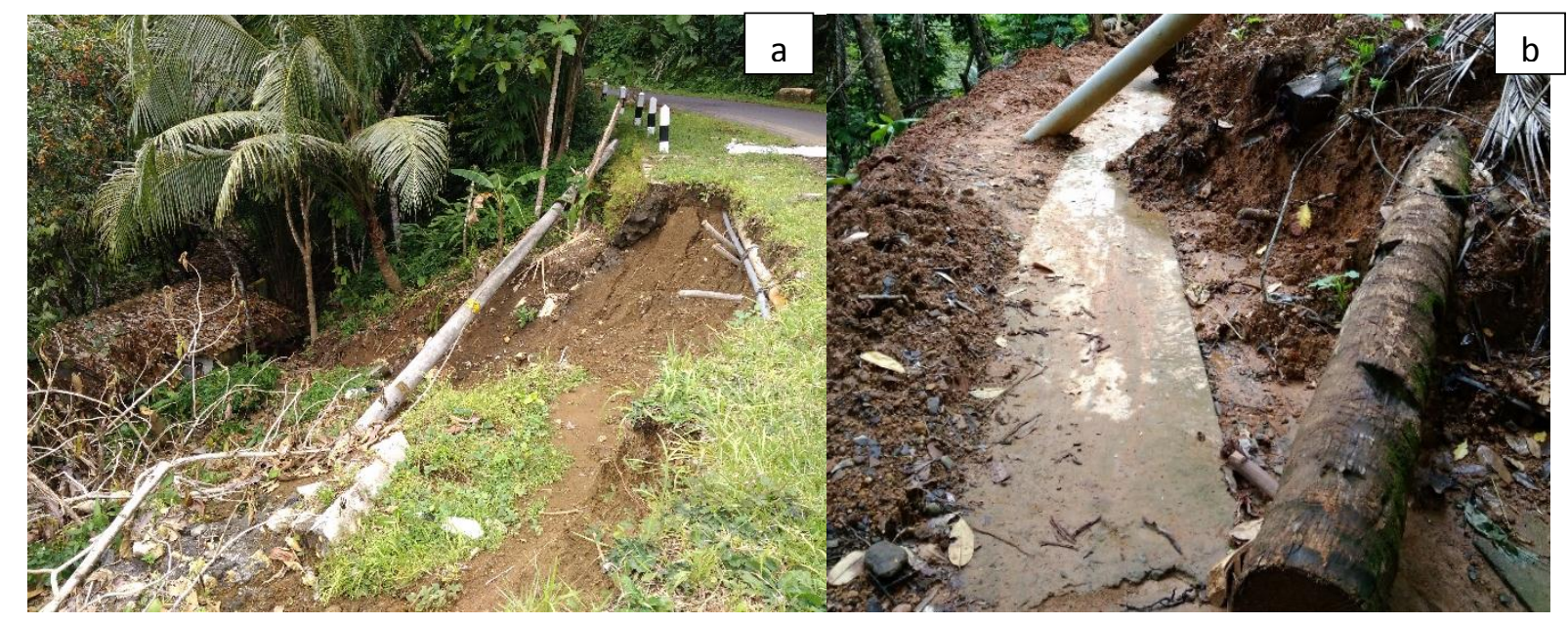

Sumber: Data primer diolah (2018)

Gambar 1. Penampakan Longsor di Lokasi enelitian (1a) Penampakan Longsor di Sekitar Pemukiman Warga, (1b) Penampakan Longsor di Daerah Perkebunan. 
Pramumijoyo (2017) telah meneliti dengan lebih spesifik karakteristik fluida hidrotermal yang menyebabkan alterasi batuan pada endaparan epitermal sulfidasi rendah di daerah Sangon, Kokap, yakni daerah penelitian yang terletak di sebelah barat laut dari Desa Hargotirto. Oleh karena itu, kajian penentuan zona kerentanan longsor di Desa Hargotirto yang kemungkinan besar dipengaruhi oleh faktor-faktor geologi tersebut penting dilakukan. Lokasi penelitian secara administratif meliputi empat desa, yaitu Desa Hargotirto, Hargowilis, Hargorejo, dan Kalirejo, Kecamatan Kokap, Kabupaten Kulon Progo, DIY dapat ditempuh dari Kota Yogyakarta sekitar satu jam dengan kendaraan bermotor ke arah barat (Gambar 2).

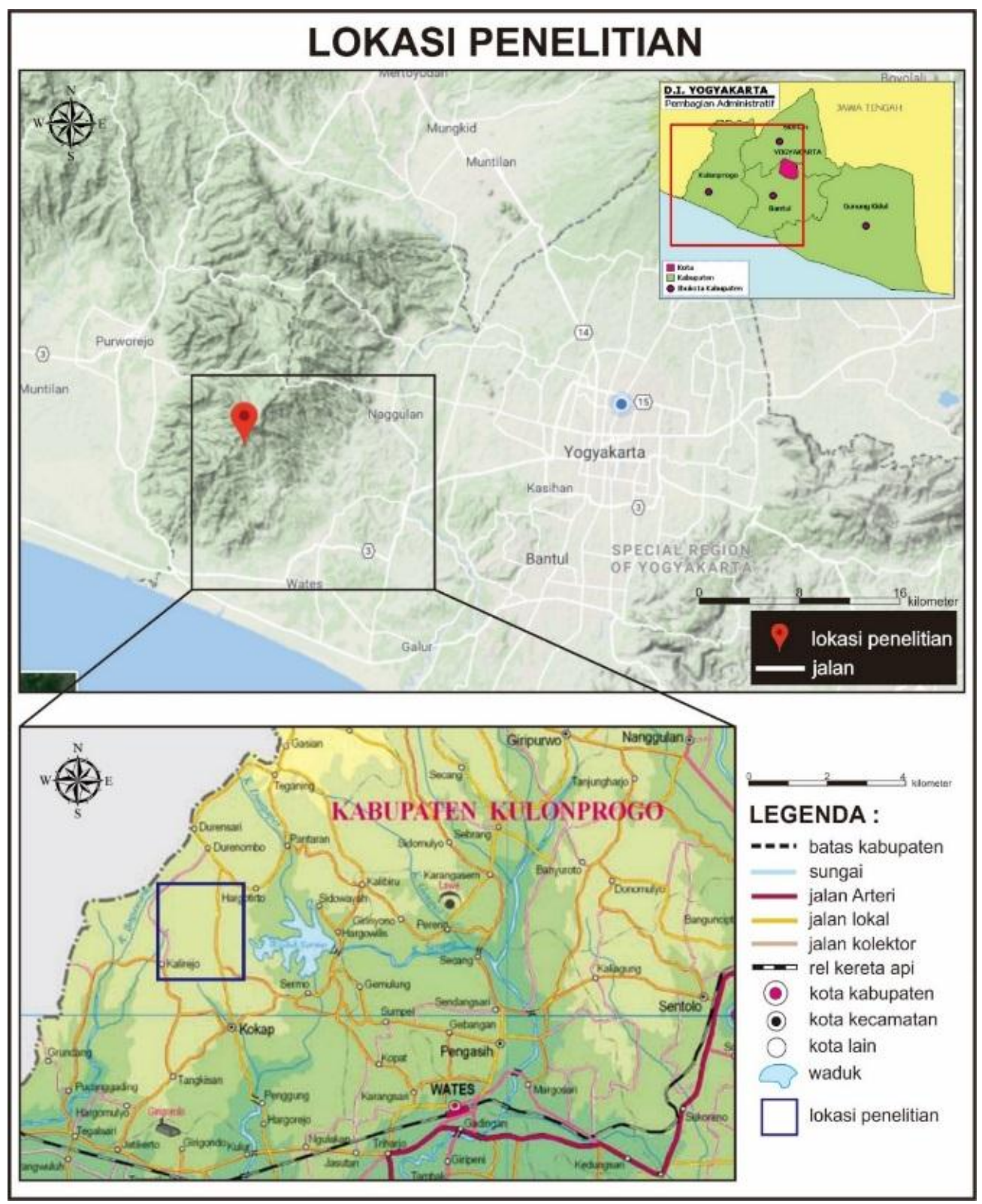

Sumber: Husna (2018)

Gambar 2. Lokasi Daerah Penelitian Desa Hargotirto, Kecamatan Kokap, Kabupaten Kulon Progo, Daerah Istimewa Yogyakarta. 


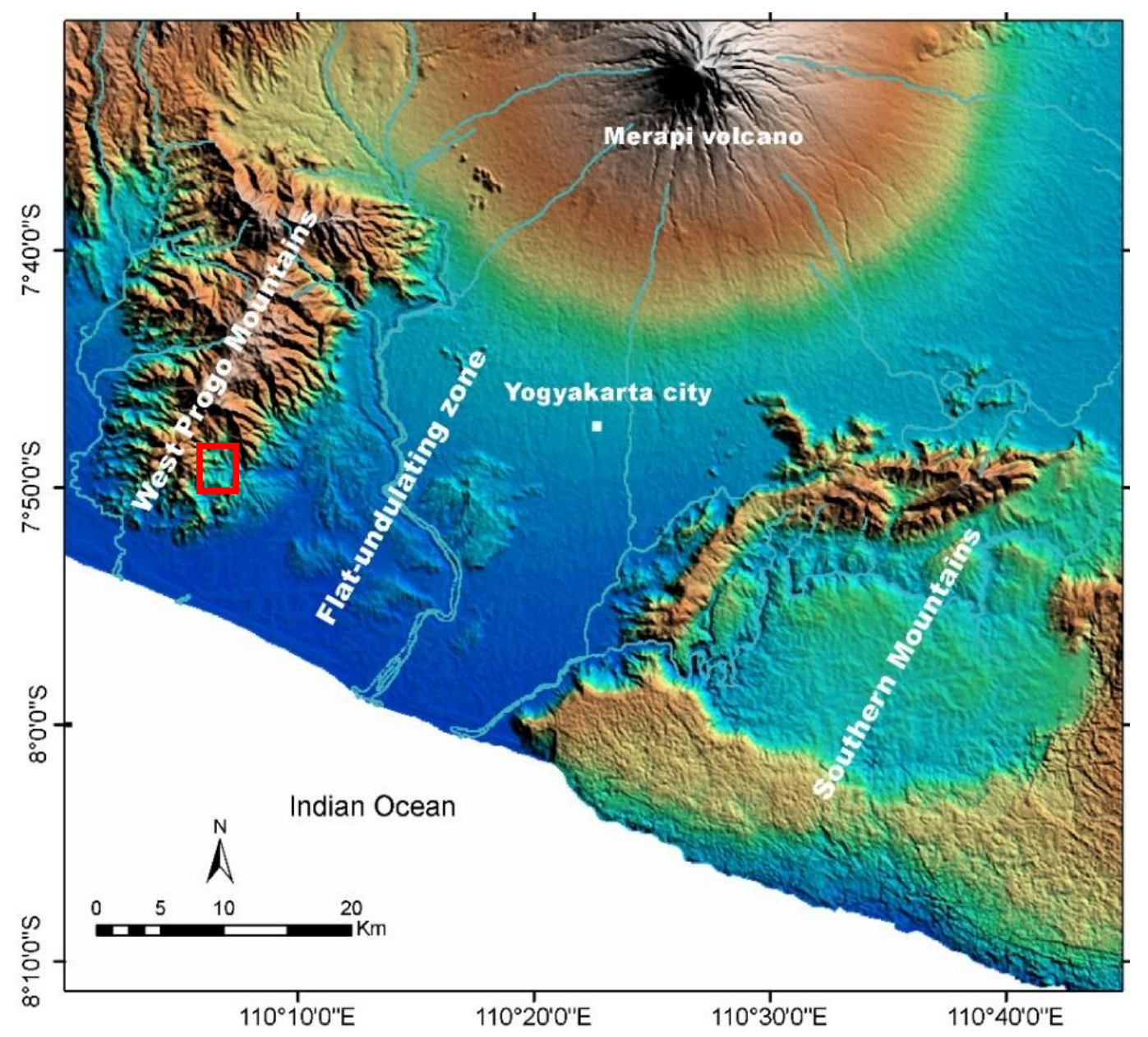

Sumber: Barianto et al. (2009)

Gambar 3. Letak wilayah Pegunungan Kulon Progo berbatasan dengan Flat-undulating Zone di sebelah timur, berbatasan dengan Gunung Merapi di sebelah utara, dan berbatasan dengan Samudra Hindia di sebelah selatan. Kotak merah menunjukan lokasi daerah peneltian.

Tujuan penelitian ini adalah menentukan zona kerentanan longsor berdasarkan karakteristik geologi dan alterasi batuan di Desa Hargotirto dan sekitarnya. Penelitian ini diharapkan dapat berkontribusi dalam meminimalkan risiko bencana akibat tanah longsor.

Berdasarkan pembagian zona fisiografi oleh Bemmelen (1949) diketahui bahwa wilayah penelitian berada di zona Serayu Selatan, tepatnya di Pegunungan Kulon Progo. Hal tersebut konsisten dengan pengelompokan fisiografi yang telah dilakukan oleh Barianto et al. (2009), yakni daerah penelitian terletak di Pegunungan Kulon Progo (Gambar 3). Geomorfologi daerah penelitian terletak pada ketinggian 100-300 meter di atas permukaan air laut.

Menurut Rahardjo et al. (1995), stratigrafi zona pegunungan Kulon Progo tersusun atas batuan vulkanik kuarter dan endapan aluvial serta kompleks batuan terobosan. Formasi-formasi batuan penyusun tersebut tersusun dari yang tua ke muda, yaitu Formasi Nanggulan, Formasi Kebo Butak, Formasi Jonggrangan, Formasi Sentolo, Endapan aluvial serta volkanik kuarter, dan kompleks batuan terobosan. Adapun daerah penelitian berada pada formasi kompleks batuan terobosan, yakni berupa batuan andesit (Gambar 4). Struktur geologi yang berkembang di 
wilayah Kulon Progo adalah sesar geser dan sesar turun yang membentuk pola radial. Pola struktur tersebut kemungkinan terbentuk karena kegiatan vulkanik dan intrusi.

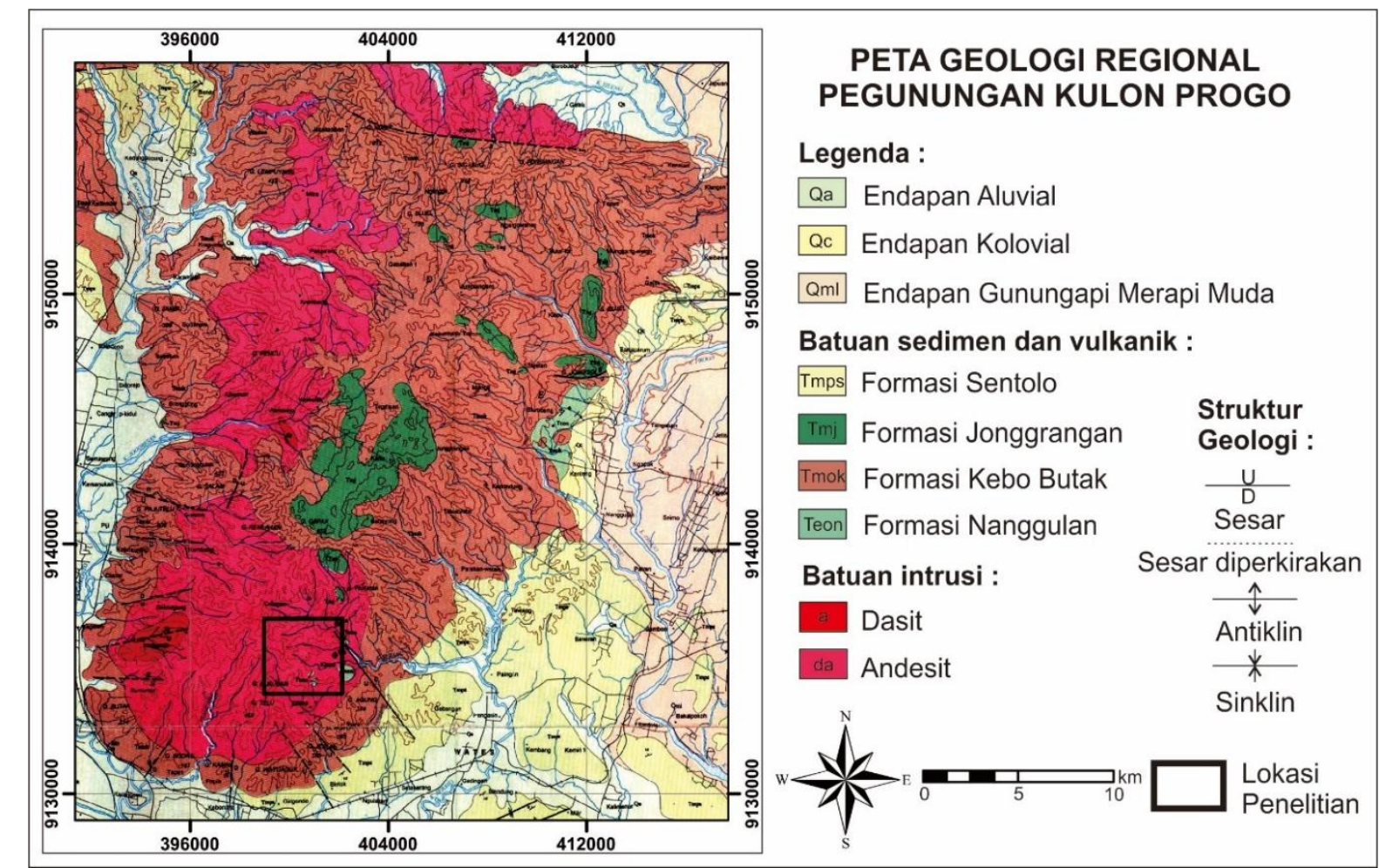

Sumber: Rahardjo et al. (1995)

Gambar 4. Peta Geologi Regional Bagian Barat Daya dari Peta Geologi Regional Lembar Yogyakarta dan Posisi Daerah Penelitian

\section{METODE}

Analisis yang digunakan dalam penelitian ini adalah pengumpulan data lapangan dan analisis laboratorium. Data-data yang dikumpulkan di lapangan, antara lain, tingkat kemiringan lereng, jenis penutup lahan, tingkat struktur massa batuan, kondisi geomorfologi, dan kondisi geologi yang meliputi jenis batuan, kondisi alterasi batuan, serta struktur geologi. Analisis yang dilakukan di laboratorium pada sampel-sampel batuan yang diambil dari lapangan, yaitu analisis petrografi, analisis XRD ( $X$-Ray Diffraction), dan analisis geokimia menggunakan ICP-AES (Inductively Coupled Plasma-Atomic Emission Spectroscopy). Analisis petrografi terhadap lima belas sampel batuan untuk mengetahui tekstur dan tingkat alterasi batuan dilakukan di Laboratorium Geologi Optik, Departemen Teknik Geologi UGM. Analisis XRD terhadap delapan sampel batuan untuk mengetahui jenis mineral lempung yang terkandung pada batuan yang teralterasi dilakukan di Laboratorium Pusat, Departemen Teknik Geologi UGM. Analisis ICP-AES pada enam sampel dilakukan di Laboratorium ALS Canada Ltd untuk mengetahui kandungan (persentase berat) senyawa oksida utamanya yang dipakai untuk menentukan atau menghitung intensitas alterasi batuan.

Hasil analsisis tersebut kemudian digunakan untuk mengetahui karakteristik geologi dan alterasi batuan yang merupakan parameter yang memengaruhi tingkat kerentanan longsor. 
Pembuatan peta kerentanan longsor dilakukan dengan metode Analytical Hierarcy Process (AHP). Metode ini menggabungkan beberapa parameter dengan pembobotan tertentu yang mempengaruhi terjadinya longsor. Adapun parameter-parameter yang dipakai dalam penelitian ini mengacu pada Direktorat Jendral Penataaan Ruang (2007).

\section{HASIL DAN PEMBAHASAN}

\subsection{Kondisi Geologi dan Alterasi Daerah Penelitian di Desa Hargotirto}

Untuk mengetahui litologi penyusun dan struktur geologi daerah penelitian dilakukan pengamatan di lapangan pada lima puluh titik lokasi pengamatan yang kemudian menghasilkan peta lokasi pengamatan dan titik lokasi sampling (Gambar 5). Berdasarkan hasil pengamatan lapangan dan data tersebut, daerah penelitian dapat dikelompokkan menjadi dua satuan batuan penyusun, yaitu Satuan Intrusi Andesit yang mencakup 55\% wilayah penelitian dan Satuan Diorit Porfiri yang mencakup 45\% wilayah penelitian (Gambar 6).

Mineral penyusun kedua satuan batuan tersebut hampir sama, yakni plagioklas, kuarsa, klinoprioksen, hornblenda, dan mineral opak yang memiliki tekstur batuan yang berbeda. Dari hasil pengamatan petrografi, andesit memperlihatkan tekstur porfiro-afanitik, sedangkan diorit porfiri memiliki tekstur fanero-porfiritik (Gambar 7). Struktur geologi daerah penelitian dicerminkan oleh kelurusan-kelurusan yang cenderung berorientasi barat-timur (Gambar 6 dan Gambar 8).

Kondisi alterasi batuan yang dijumpai di daerah penelitian dibedakan menjadi dua, yaitu tipe alterasi dan intensitas alterasinya. Tipe alterasi dikelompokkan menjadi tipe argilik dan tipe propilitik. Mineral penciri alterasi argilik yang diidentifikasi dari analisis petrografi memperlihatkan adanya mineral lempung (Gambar 9). Analisis XRD menunjukan jenis mineral lempung yang berupa kaolinit, montmorillonit, dan smektit (Tabel 1). Adapun tipe alterasi propilitik dicirikan oleh kehadiran mineral klorit, dan zeolit dari hasil pengamatan petrografi (Gambar 10). Mineral-mineral lempung tersebut bersifat impermeabel sehingga sangat mudah berfungsi sebagai zona bidang gelincir yang akan memicu terjadinya longsor.

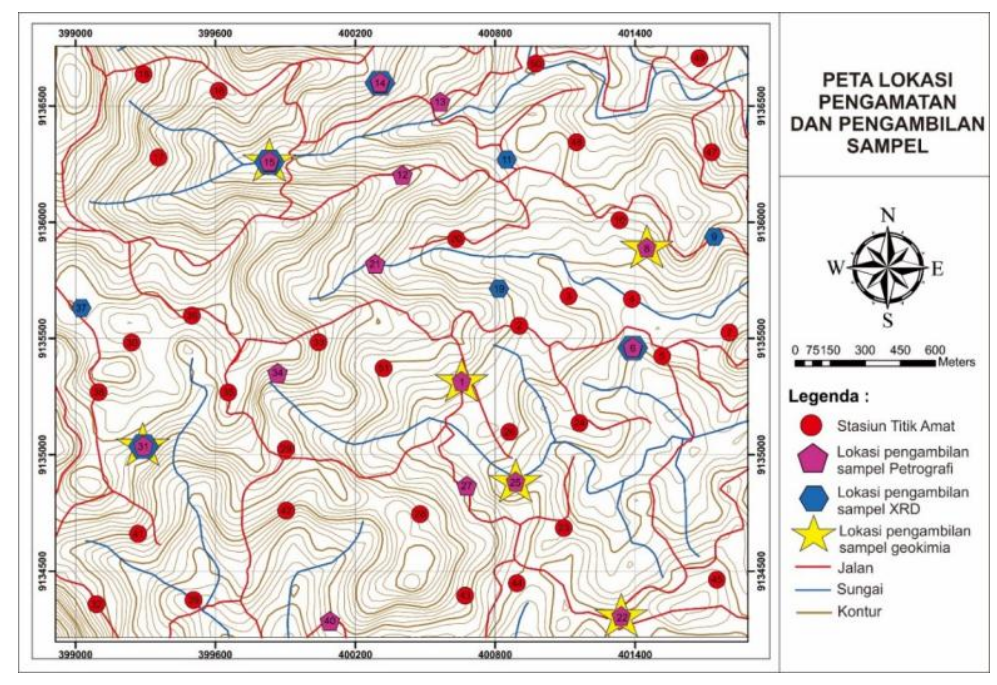

Sumber: Husna (2018)

Gambar 5. Peta Stasiun Titik Amat dan Lokasi Pengambilan Sampel di Desa Hargotirto untuk Analisis Laboratorium 


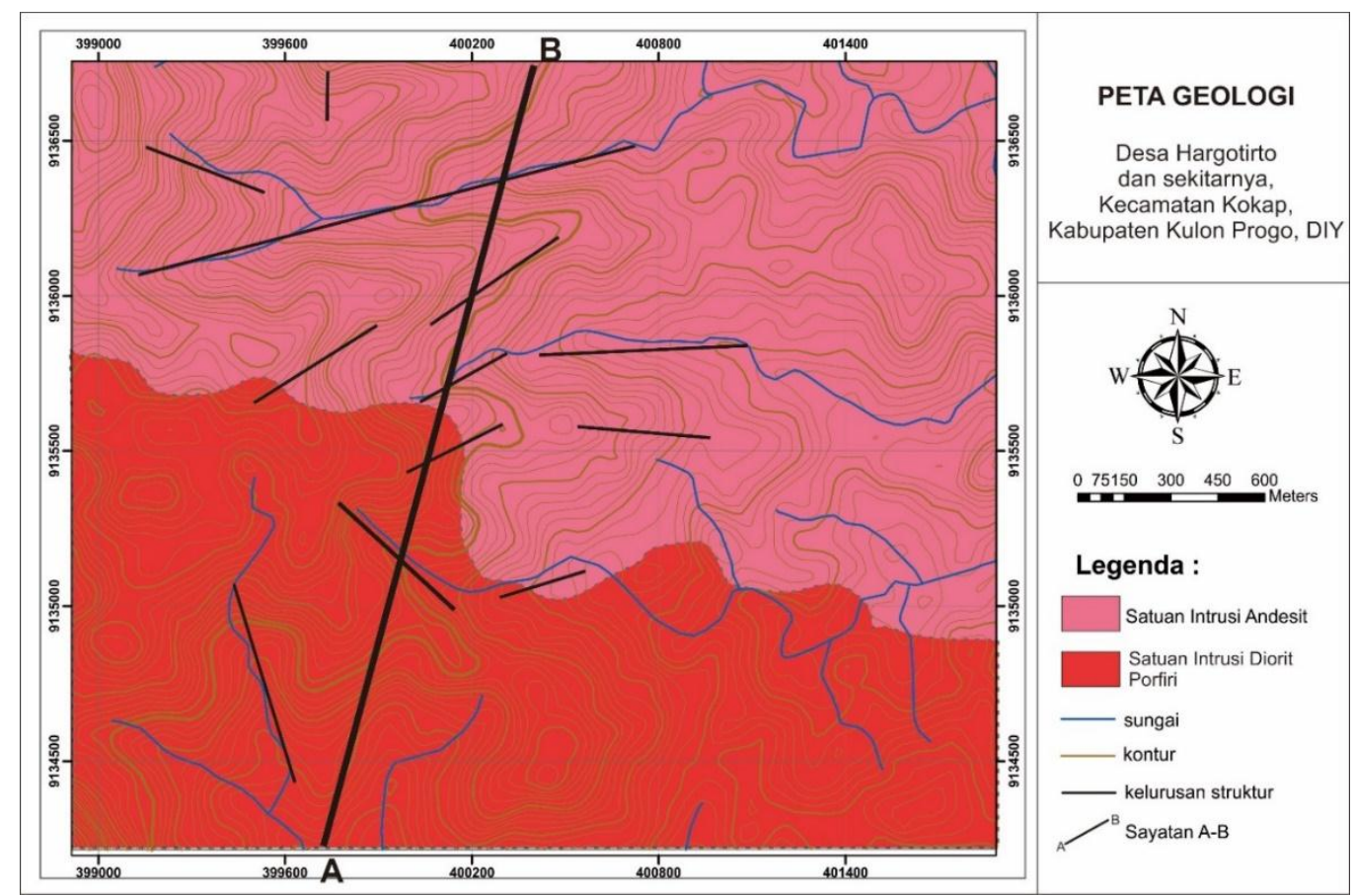

Sumber: Husna (2018)

Gambar 6. Peta Geologi Daerah Penelitian di Desa Hargotirto yang Memperlihatkan Litologi Penyusunnya, yakni Satuan Intrusi Andesit dan Satuan Intrusi Diorit Porfiri

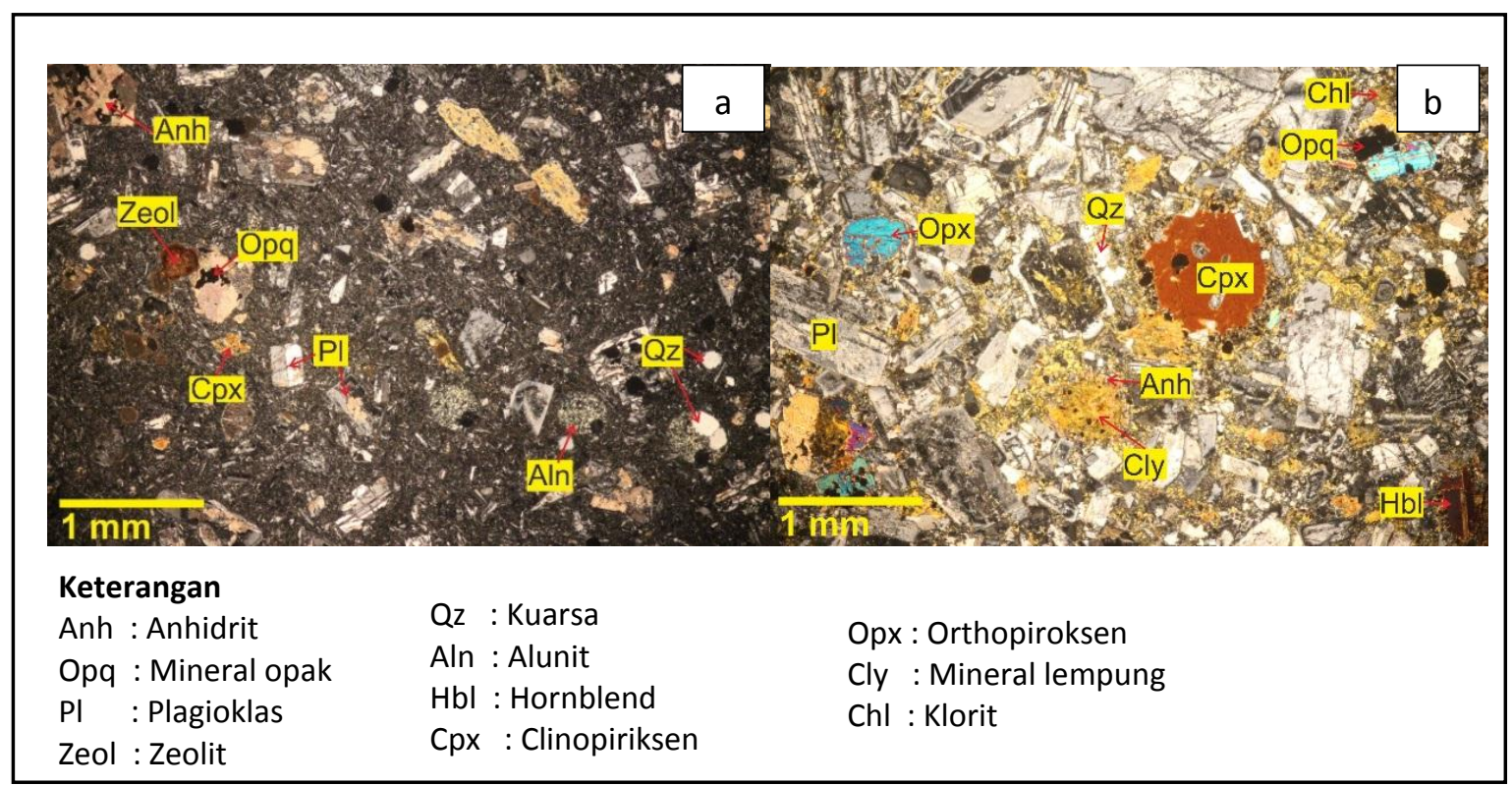

Sumber: Husna (2018)

Gambar 7. Fotomikrograf Sayatan Petrografi Batuan pada Nikol Bersilang (a) Andesit yang Memperlihatkan Tekstur Porfiro-Afanitik, (b) Diorit Porfiri yang Memperlihatkan Tekstur Fanero Porfiritik 


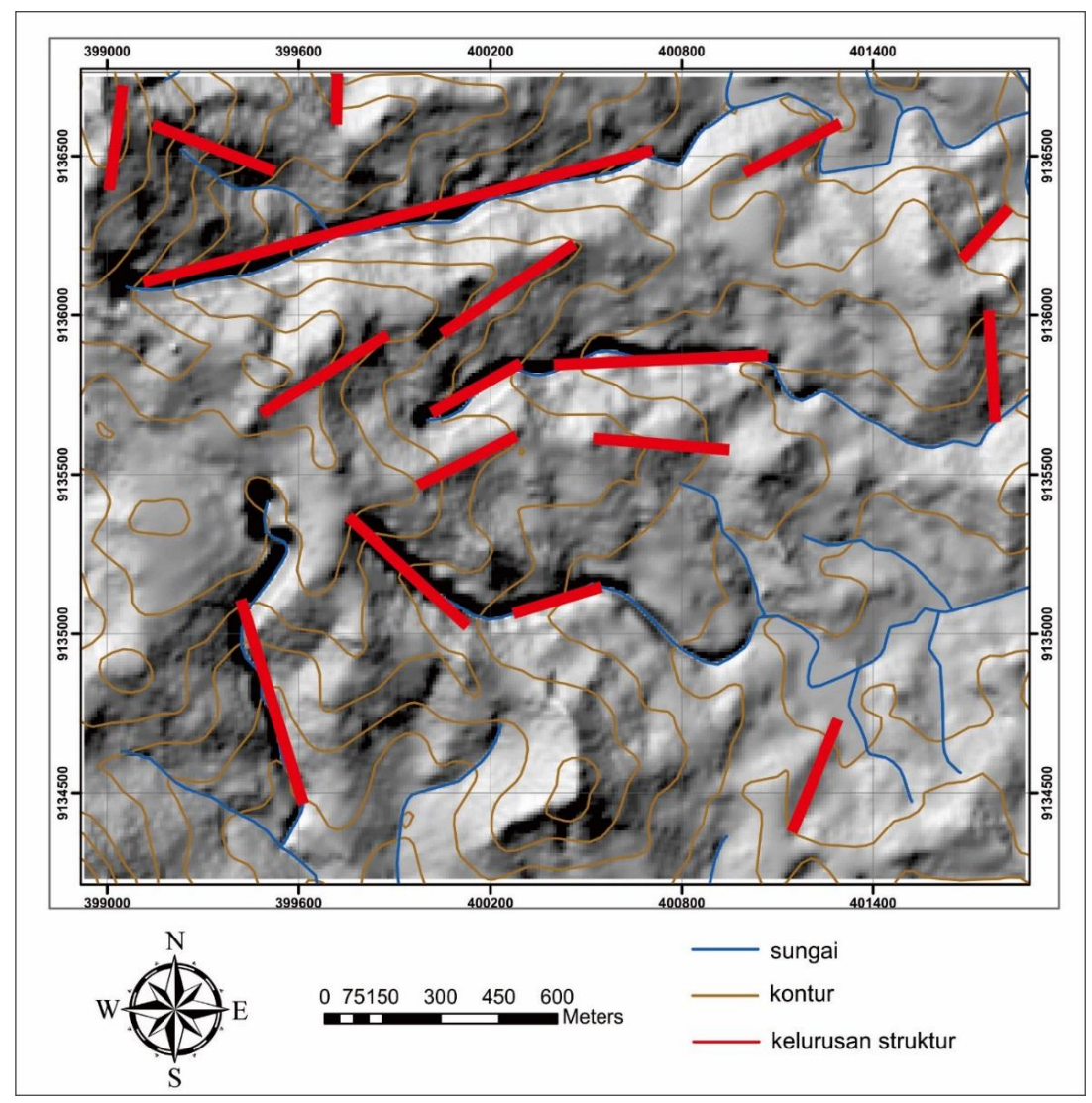

Sumber: Husna (2018)

Gambar 8. Kelurusan Berarah Barat-Timur yang Menunjukan Kecenderungan Arah Struktur Geologi pada Daerah Penelitian di Desa Hargotirto

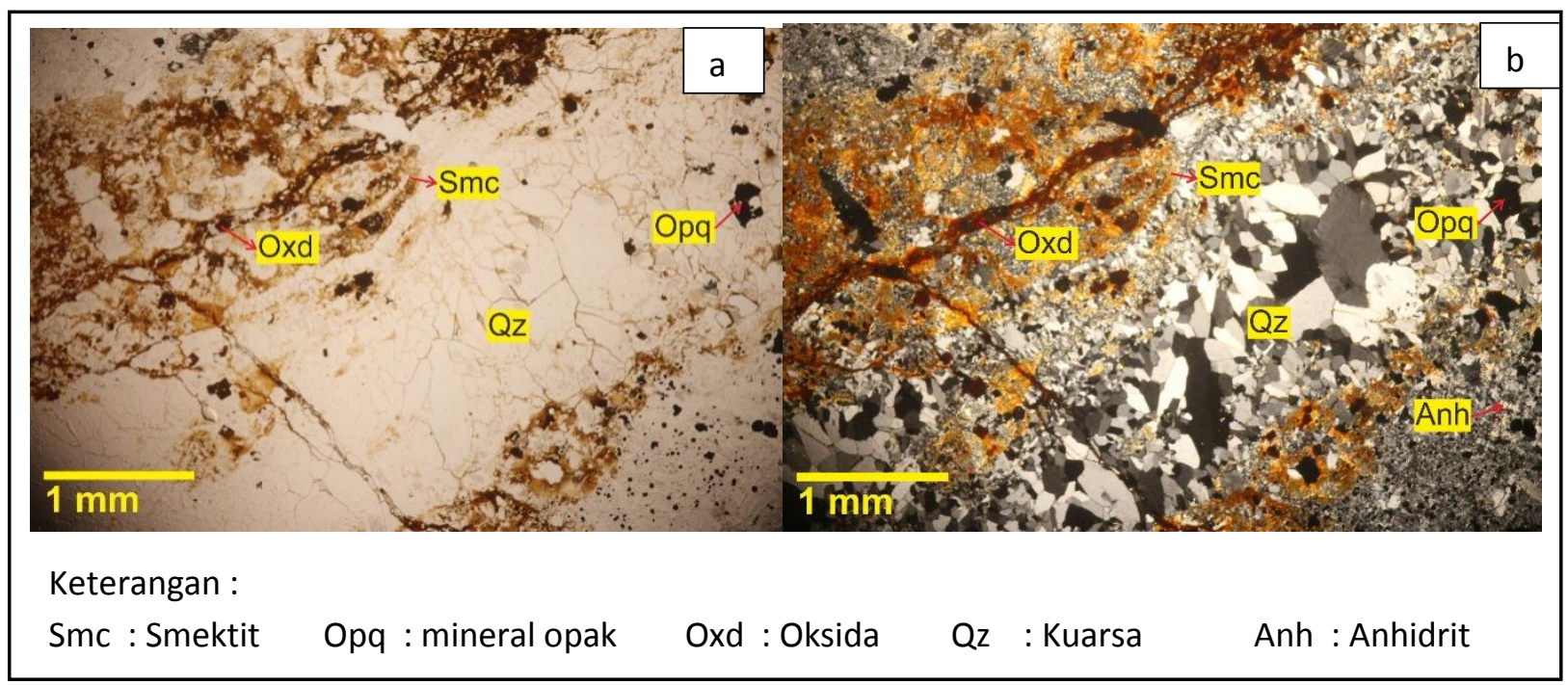

Sumber: Husna (2018)

Gambar 9. Fotomikrograf Petrografi Batuan dari Daerah Penelitian di Desa Hargotirto yang Telah Teralterasi Argilik Dicirikan dengan Kehadiran Mineral Smektit (A) Medan Pandang pada Nikol Sejajar, (B) Medan Pandang pada Nikol Bersilang. 
Tabel 1. Hasil Analisis X-ray Diffraction (XRD)

\begin{tabular}{|c|c|c|c|}
\hline No. Sampel & Analisis Bulk & Analisis Clay & Jenis Alterasi \\
\hline HG 3 & $\begin{array}{l}\text { kuarsa, kristobalit, plagioklas, } \\
\text { kalsit, alunit, feldspar }\end{array}$ & Smektit, Illit, kaolin & Argilik \\
\hline HG 5 & $\begin{array}{c}\text { khematit, kuarsa, kalsit, kristobalit, } \\
\text { alunit }\end{array}$ & $\begin{array}{l}\text { Smektit (montmorillonit), } \\
\text { Illit, kaolin, Klorit }\end{array}$ & Argilik \\
\hline HG 7 & $\begin{array}{c}\text { pirit, plagioklas, kuarsa, kristobalit, } \\
\text { hematit, kalsit }\end{array}$ & Smektit, Illit, kaolin, Klorit & Argilik \\
\hline HG 9 & $\begin{array}{l}\text { magnetit, alunit, kristobalit, } \\
\text { plagioklas, magnetit, kuarsa }\end{array}$ & Smektit, Illit, kaolin, Klorit & Argilik \\
\hline HG 10 & $\begin{array}{l}\text { pirit, biotit, kuarsa, kalsit, hematit, } \\
\text { alunit, hornblend, kuarsa, } \\
\text { kristobalit }\end{array}$ & smektit, Illit & Argilik \\
\hline HG 11 & $\begin{array}{l}\text { kristobalit, kuarsa, pirit, hematit, } \\
\text { plagioklas, feldspar, magnetit }\end{array}$ & $\begin{array}{l}\text { Smektit (montmorillonit), } \\
\text { Illit, kaolin, Klorit }\end{array}$ & Argilik \\
\hline HG 17 & $\begin{array}{l}\text { kuarsa, kristobalit, plagioklas, } \\
\text { feldsapar }\end{array}$ & smektit, illlit, kaolini & Argilik \\
\hline HG 20 & plagioklas, kuarsa, hematit, kalsit & kaolin, klorit, smektit & Argilik \\
\hline
\end{tabular}

Sumber: Data primer diolah (2018)

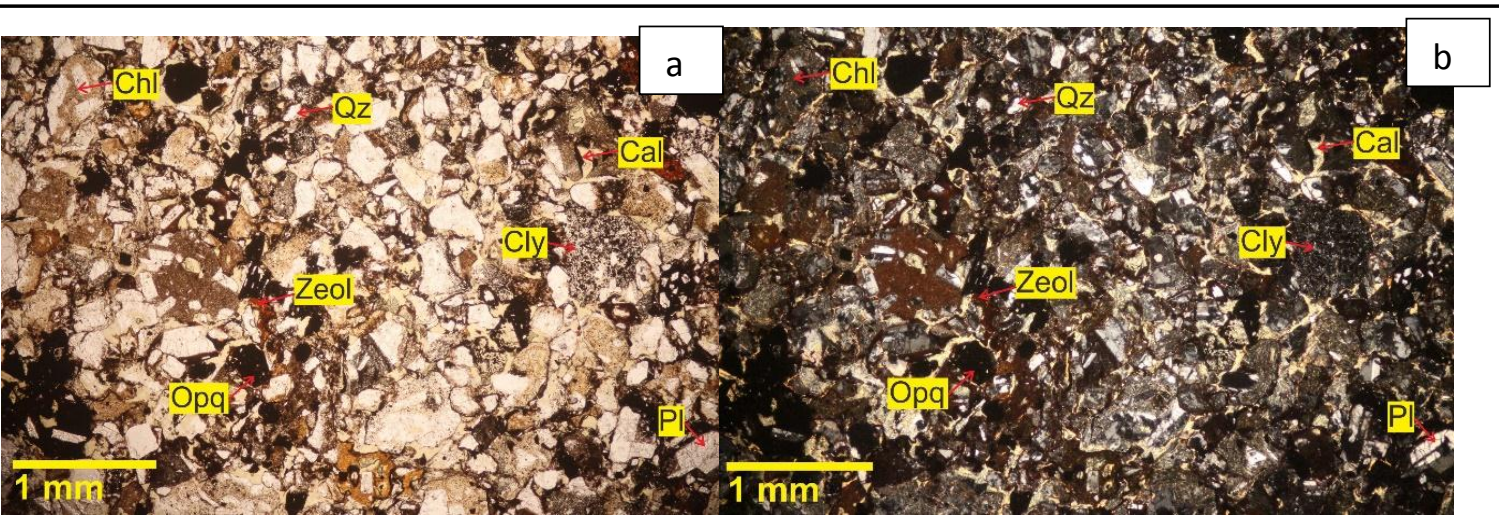

$$
\begin{array}{lll}
\text { Keterangan } & & \\
\text { Chl : Klorit } & \text { Opq : Mineral opak } & \text { Cly : mineral lempung } \\
\text { Qz : Kuarsa } & \text { PI : Plagioklas } & \\
\text { Zeol : Zeolit } & \text { Cal : kalsit } &
\end{array}
$$

Sumber: Husna (2018)

Gambar 10 Fotomikrograf Petrografi Batuan dari Daerah Penelitian di Desa Hargotirto yang Memperlihatkan Tipe Alterasi Propilitik Dengan Dicirikan oleh Kehadiran Mineral Klorit dan Zeolit. (A) Medan Pandang pada Nikol Sejajar, (B) Medan Pandang pada Nikol Bersilang

Tipe alterasi argilik menempati bagian utara sampai tengah dan melingkupi kurang lebih $45 \%$ dari wilayah penelitian, sedangkan tipe alterasi propilitik menempati sebagian daerah tengah sampai selatan dan mencakup $20 \%$ dari wilayah penelitian. Wilayah selatan yang 
mencakup 35\% dari wilayah daerah penelitian disusun oleh batuan yang relatif masih segar (Gambar 11).

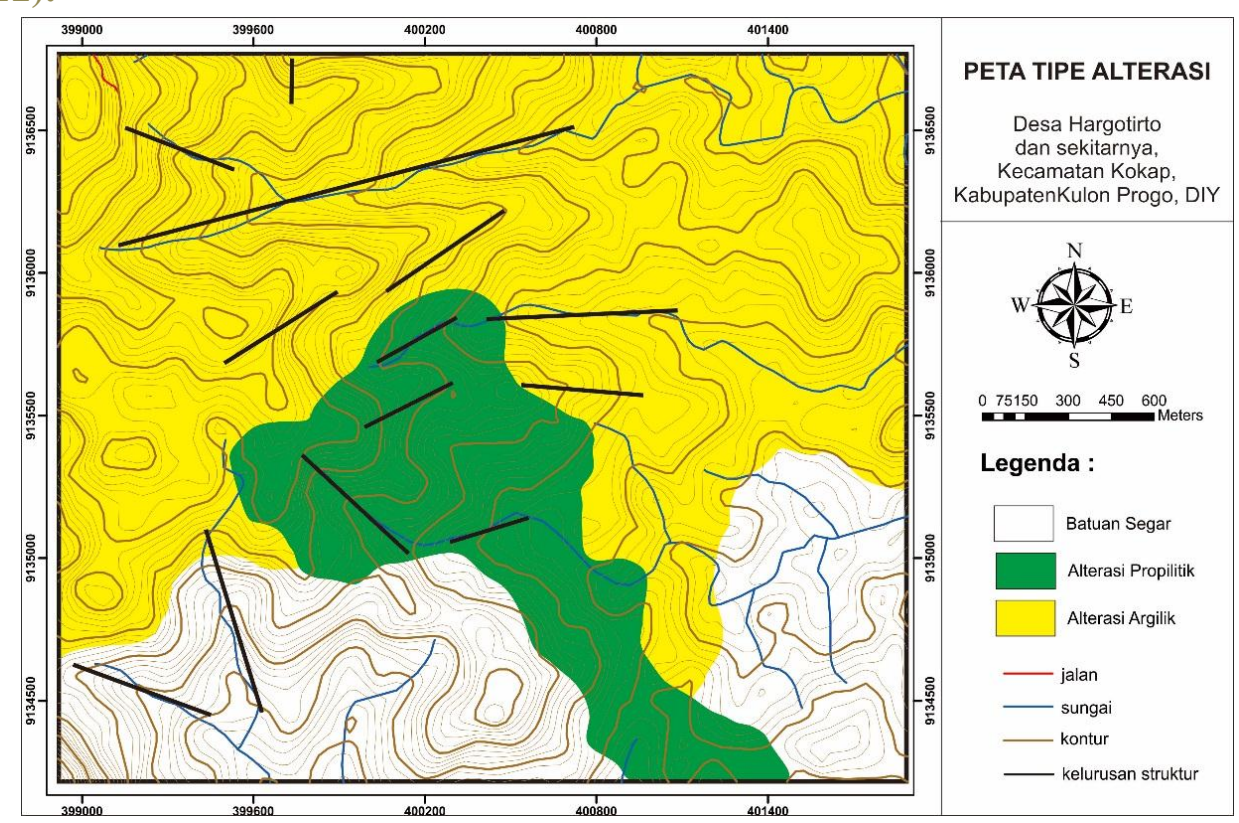

Sumber: Husna (2018)

Gambar 11. Peta Tipe Alterasi Daerah Penelitian di Desa Hargotirto yang Menunjukan Dua Tipe Alterasi Batuan, yaitu Propilitik dan Argilik

Intensitas alterasi dapat diketahui melalui penggabungan antara pengamatan petrografi dan pengeplotan pada diagram alterasi menggunakan hasil perhitungan dari data persentase oksida utama. Diagram alterasi merujuk pada diagram Large et al. (2001) (Gambar 12).

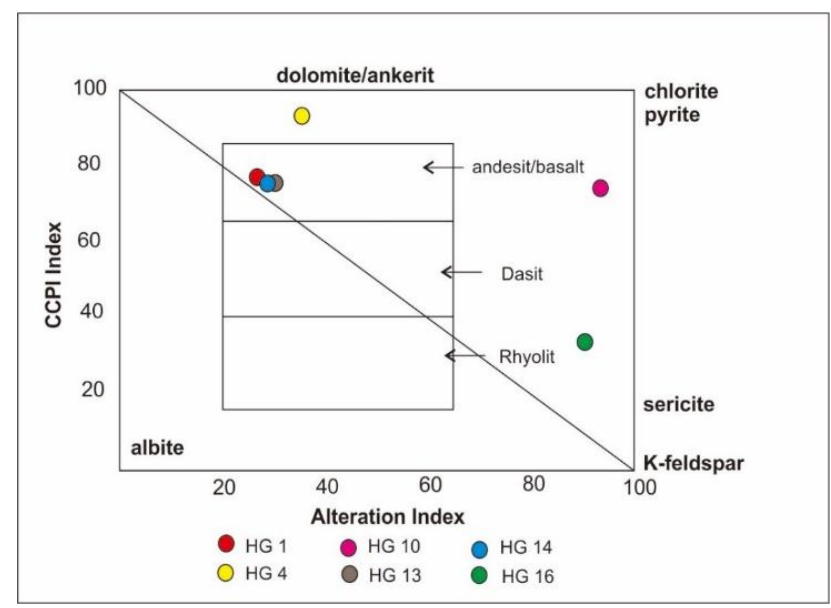

Sumber: Data primer diolah (2018)

Gambar 12 Hasil Plotting Perhitungan CCPI Index dan Alteration Index Berdasarkan Data Geokimia pada Diagram Alteration Box Plot yang merujuk pada Diagram Large, et al. (2001)

Pada diagram tersebut, tiga sampel batuan ter-plot di luar domain least altered yang berarti sampel-sampel tersebut merupakan batuan yang telah mengalami alterasi dengan intensitas tinggi. Adapun tiga sampel batuan lainnya berada di dalam domain least altered yang berarti bahwa sampel tersebut berada pada kondisi teralterasi dengan intensitas rendah sekaligus 
menunjukkan jenis batuannya, yaitu andesit atau basal (Gambar 12). Berdasarkan intensitas alterasinya, batuan di daerah penelitian dapat dikelompokkan dalam empat tingkat, yaitu tidak teralterasi (mineral sekunder $<2 \%$ ), intensitas rendah (mineral sekunder 2-9\%), intensitas sedang (mineral sekunder 10-49\%), dan intensitas tinggi (mineral sekunder 50-90\%). Intensitas alterasi tinggi mendominasi 35\% dari keseluruhan wilayah penelitian (Gambar 13).

\subsection{Penentuan Zona Longsor di Desa Hargotirto}

Untuk menentukan zona kerentanan longsor digunakan metode Analytical Hierarcy process (AHP) yang diperkenalkan oleh Saaty et al. (2008). Nilai bobot masing-masing parameter ditentukan berdasarkan kondisi geologi di lapangan. Berdasarkan pengamatan dan pengumpulan data di lapangan, parameter yang digunakan untuk menentukan zona kerentanan longsor dari yang paling berpengaruh hingga yang kurang berpengaruh adalah kondisi alterasi, jenis penutup lahan, struktur massa batuan, dan kemiringan lereng (Tabel 2 dan Tabel 3).

Parameter yang pertama adalah kondisi alterasi. Nilai parameter ini menjadi yang paling utama karena faktor alterasi sangat menentukan kestabilan lereng yang akan menentukan tingkat kerentanan longsor di daerah penelitian. Peta kondisi alterasi diperoleh dari penggabungan peta intensitas alterasi dan tipe alterasi (Gambar 14).

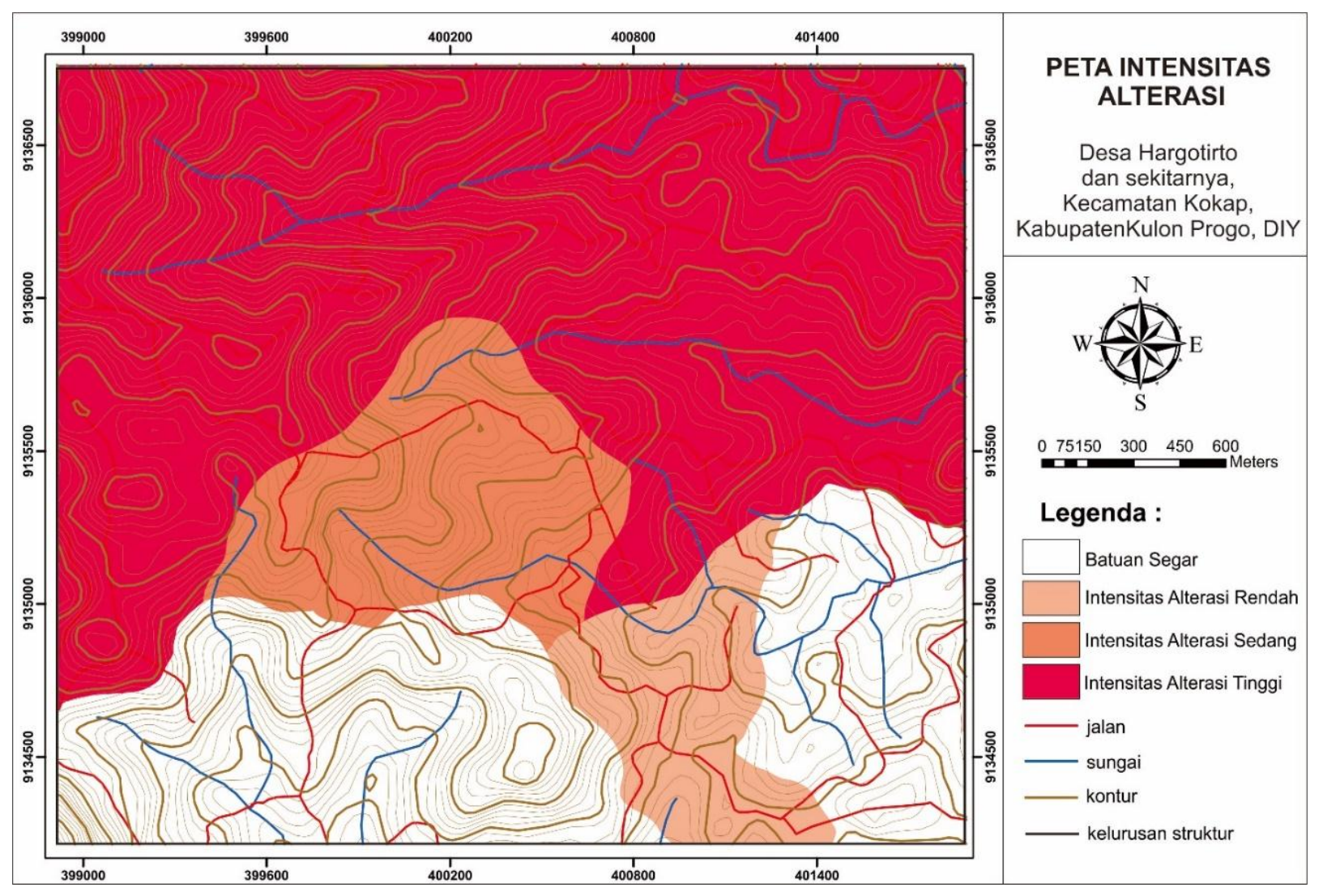

Sumber: Husna (2018)

Gambar 13. Peta Intensitas Alterasi Daerah Penelitian di Desa Hargotirto 
Tabel 2. Matriks Timbal-Balik (pair-wise comparison) yang Digunakan untuk Analisis AHP pada Daerah Penelitian di Desa Hargotirto

\begin{tabular}{ccccc}
\hline Parameter & $\begin{array}{c}\text { Kondisi } \\
\text { Alterasi }\end{array}$ & $\begin{array}{c}\text { Kemiringan } \\
\text { Lereng }\end{array}$ & $\begin{array}{c}\text { Struktur Massa } \\
\text { Batuan }\end{array}$ & $\begin{array}{c}\text { Penutup } \\
\text { Lahan }\end{array}$ \\
\hline Kondisi Alterasi & $1 / 1$ & $2 / 1$ & $4 / 1$ & $7 / 1$ \\
Kemiringan Lereng & $1 / 2$ & $1 / 1$ & $4 / 2$ & $4 / 1$ \\
Struktur Massa Batuan & $1 / 3$ & $1 / 2$ & $1 / 1$ & $2 / 1$ \\
Penutup Lahan & $1 / 7$ & $1 / 3$ & $1 / 4$ & $1 / 1$ \\
\hline Parameter & Kondisi & Kemiringan & Struktur Massa & Penutup \\
& Alterasi & Lereng & Batuan & Lahan \\
\hline Kondisi Alterasi & 1,00 & 2,00 & 4,00 & 7,00 \\
Kemiringan Lereng & 0,50 & 1,00 & 2,00 & 4,00 \\
Struktur Massa Batuan & 0,33 & 0,50 & 1,00 & 2,00 \\
Penutup Lahan & 0,14 & 0,33 & 0,25 & 1,00 \\
\hline Jumlah & 1,98 & 3,83 & 7,25 & 14,00 \\
\hline
\end{tabular}

Sumber: Data primer diolah (2018)

Tabel 3. Matriks Ternormalisasi untuk Analisis AHP pada Daerah Penelitian di Desa Hargotirto

\begin{tabular}{|c|c|c|c|c|c|c|c|}
\hline Parameter & $\begin{array}{l}\text { Kondisi } \\
\text { Alterasi }\end{array}$ & $\begin{array}{l}\text { Kemiringan } \\
\text { Lereng }\end{array}$ & $\begin{array}{c}\text { Struktur } \\
\text { Massa } \\
\text { Batuan }\end{array}$ & $\begin{array}{l}\text { Penutup } \\
\text { Lahan }\end{array}$ & Jumlah & Bobot & $\begin{array}{c}\text { Bobot } \\
(\%)\end{array}$ \\
\hline Kondisi Alterasi & 0,51 & 0,52 & 0,55 & 0,50 & 2,08 & 0,52 & 52 \\
\hline $\begin{array}{l}\text { Kemiringan } \\
\text { Lereng }\end{array}$ & 0,25 & 0,26 & 0,28 & 0,29 & 1,08 & 0,27 & 27 \\
\hline $\begin{array}{l}\text { Struktur Massa } \\
\text { Batuan }\end{array}$ & 0,17 & 0,13 & 0,14 & 0,14 & 0,58 & 0,14 & 14 \\
\hline Penutup Lahan & 0,07 & 0,09 & 0,03 & 0,07 & 0,27 & 0,07 & 7 \\
\hline Jumlah & 1 & 1 & 1 & 1 & 4,00 & 1,00 & 100 \\
\hline $\begin{array}{c}\mathrm{n}=4 \\
\Lambda \max \end{array}$ & \multirow{3}{*}{\multicolumn{7}{|c|}{ 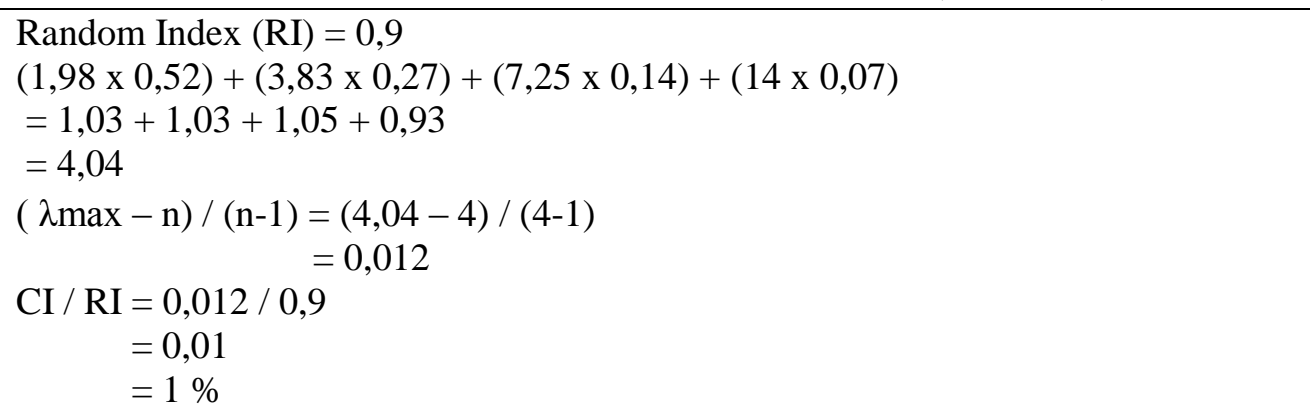 }} \\
\hline $\mathrm{CI}$ & & & & & & & \\
\hline $\mathrm{CR}$ & & & & & & & \\
\hline
\end{tabular}

Sumber: Data primer diolah (2018) 


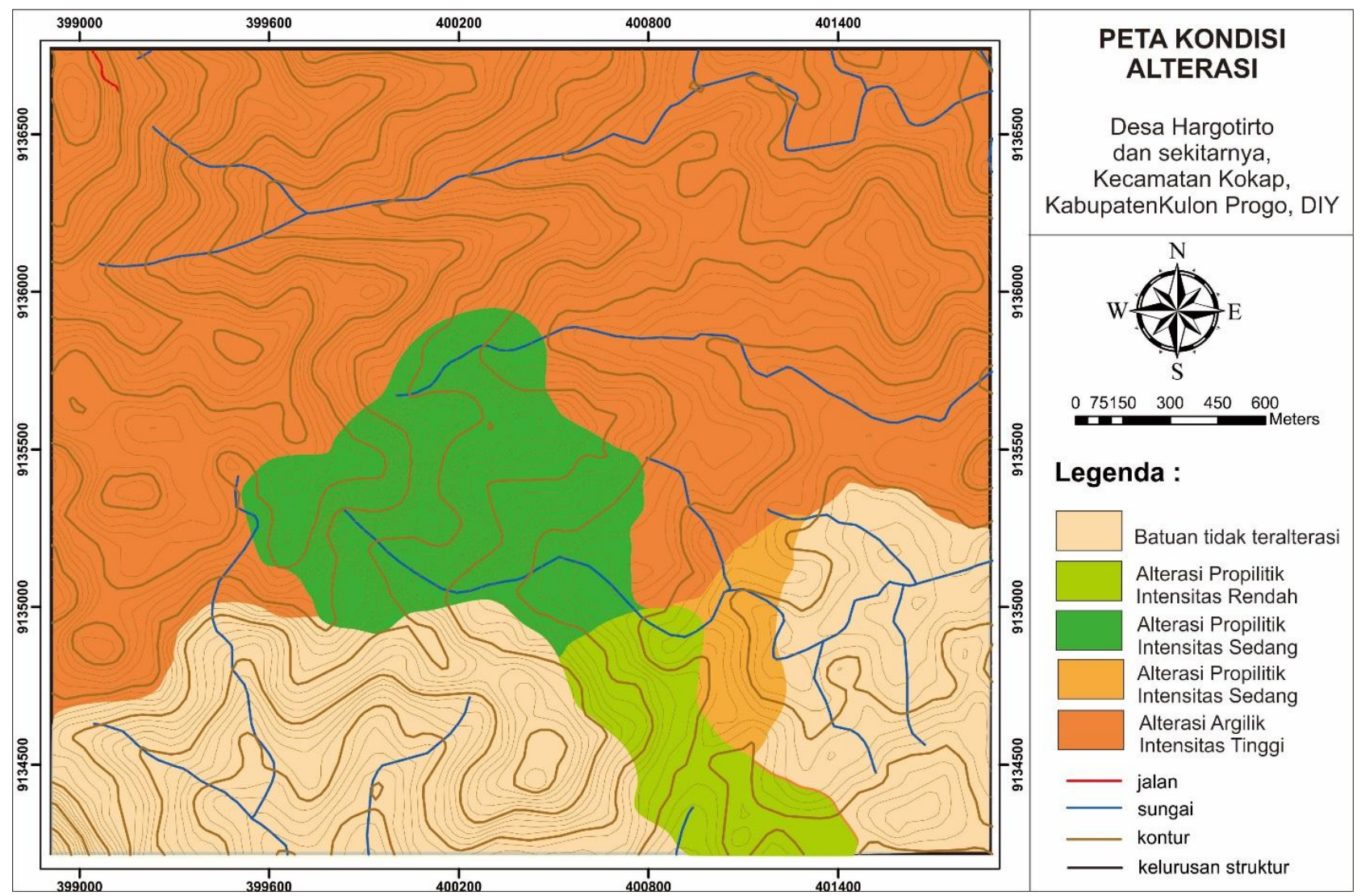

Sumber: Husna (2018)

Gambar 14 Peta Kondisi Alterasi Daerah Penelitian di Desa Hargotirto

Parameter kedua adalah struktur masa batuan. Batuan di daerah penelitian dibagi menjadi tiga jenis struktur massa batuan, yaitu disturbed-disintegrated, blocky-very blocky, dan masif. Jenis struktur batuan disturbed-disintegrated mendominasi dan mencakup kurang lebih $30 \%$ wilayah penelitian (Gambar 15). Struktur masa batuan tersebut akan sangat berpengaruh pada tingkat kestabilan lereng. Kondisi batuan yang terganggu dan tidak terintegrasi akan cenderung mengkondisikan batuan menjadi lebih tidak stabil dibandingkan batuan yang masif.

Parameter ketiga adalah jenis penutup lahan. Jenis penutup lahan berpengaruh pada tingkat kestabilan lereng. Penutup lahan yang berupa pemukiman akan menambah beban lereng sehingga lereng menjadi lebih tidak stabil. Jenis vegetasi yang menutup lahan juga berpengaruh terhadap kestabilan lereng. 


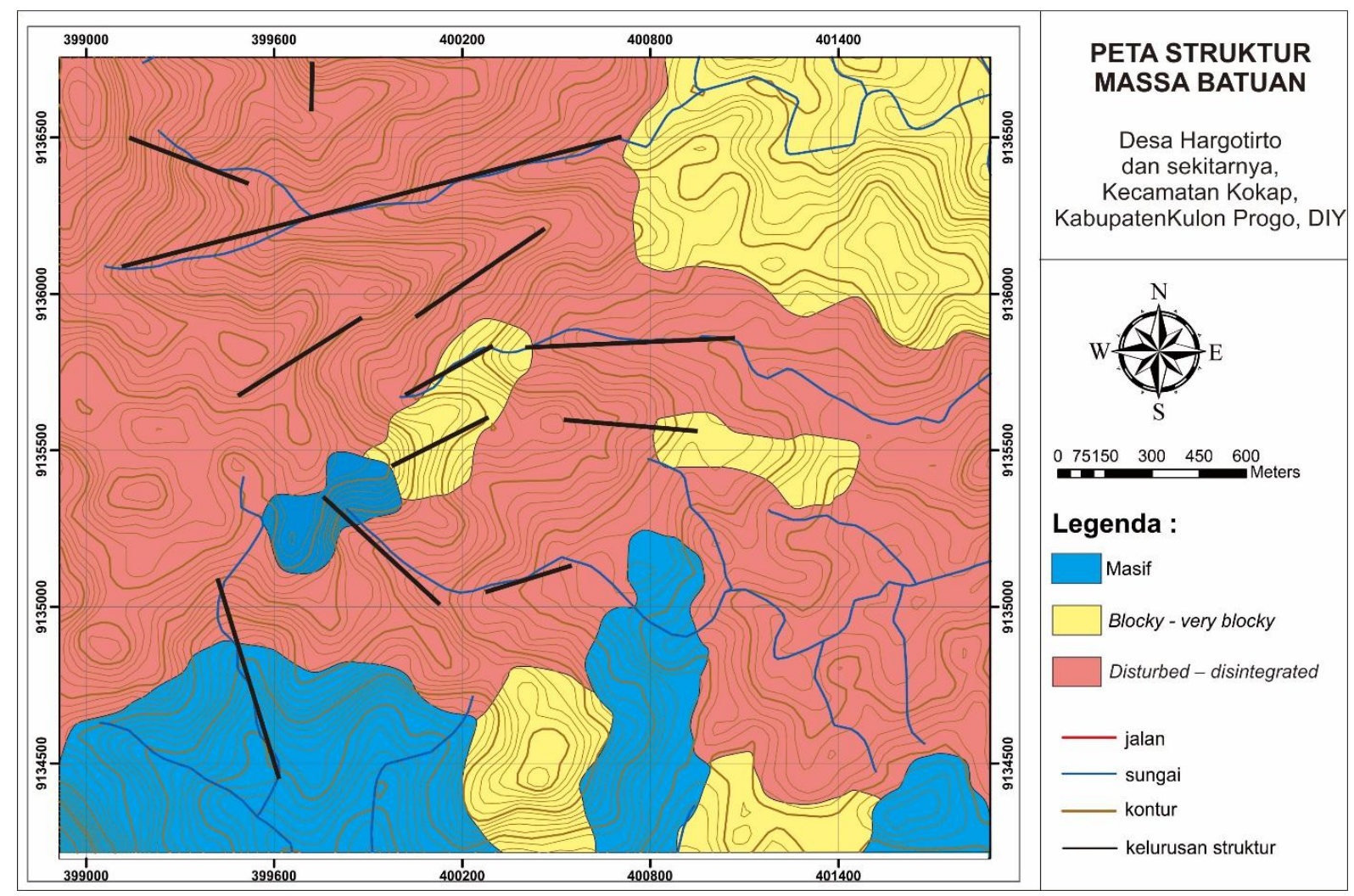

Sumber: Husna (2018)

Gambar 15 Peta Struktur Massa Batuan Daerah Penelitian di Desa Hargotirto

Tumbuhan yang banyak menyerap air dan memiliki akar tunggang akan lebih baik bagi kestabilan lereng daripada tumbuhan yang berakar serabut dan menyerap sedikit air. Jenis penutup lahan yang dijumpai di daerah penelitian adalah semak belukar, vegetasi tinggi, pemukiman, dan waduk. Sebagian besar daerah penelitian ditutup oleh vegetasi tinggi tempat pemukiman mengelompok, tetapi lebih terkonsentrasi di bagian timur laut daerah penelitian (Gambar 16).

Parameter yang terakhir adalah kemiringan lereng. Semakin besar kemiringan suatu lereng akan semakin rendah tingkat kestabilan lerengnya sehingga kemiringan lereng menjadi salah satu faktor yang sangat penting untuk menentukan tingkat kerentanan longsor. Empat tingkat kemiringan lereng yang terdapat di daerah penelitian adalah miring $\left(4-8^{\circ}\right)$, agak curam $\left(8-16^{\circ}\right)$, curam $\left(16-35^{\circ}\right)$, dan sangat curam $\left(35-55^{\circ}\right)$. Tingkat kemiringan lereng tersebut terdistribusi hampir merata di daerah penelitian (Gambar 17). Zona kemiringan agak curam di bagian timur laut daerah penelitian dan pemanfaatannya didominasi sebagai pemukiman.

Berdasarkan keempat parameter tersebut kemudian dilakukan penghitungan Analytical Hierarchy Process yang menghasilkan nilai bobot kerentanan longsor di 142 titik di lokasi pengamatan (Gambar 18). 


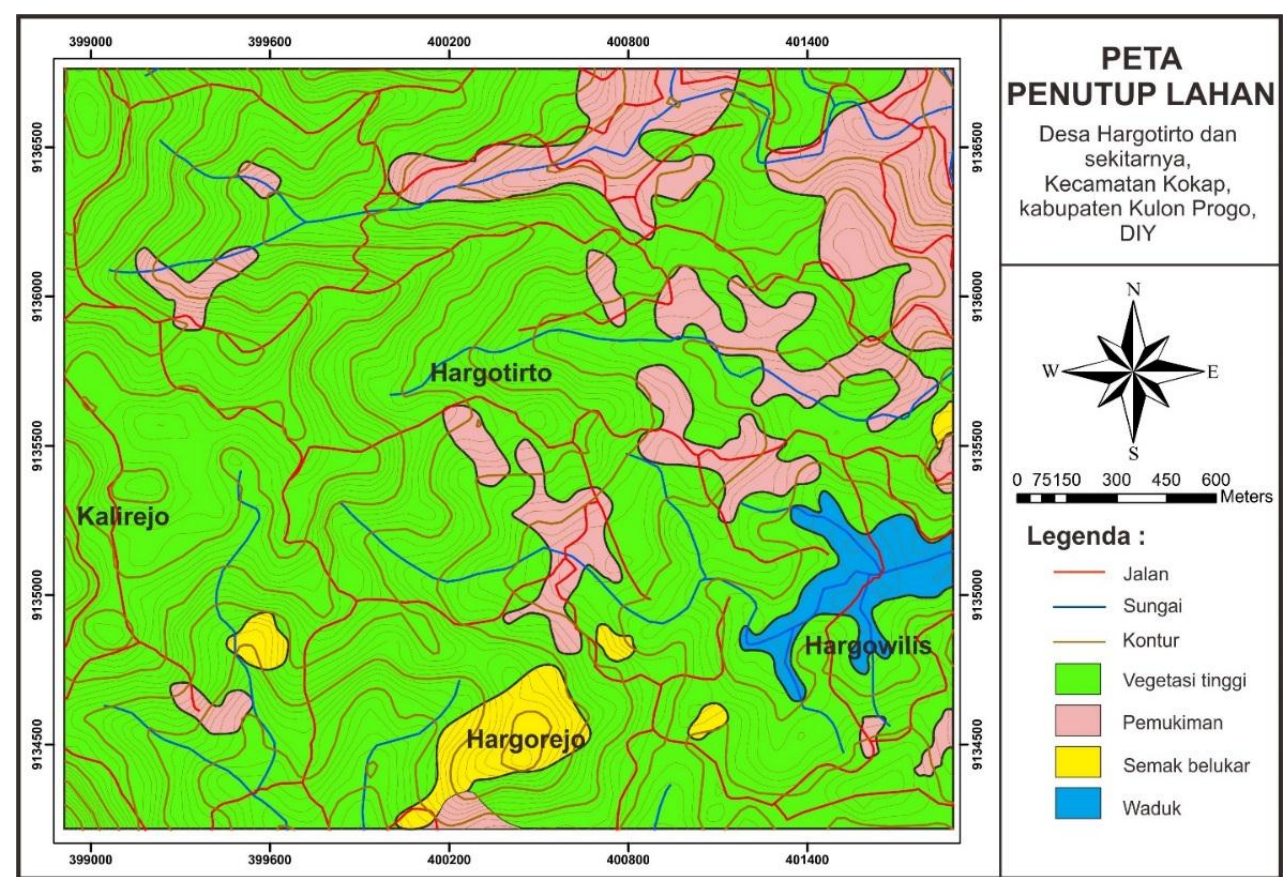

Sumber: Husna (2018)

Gambar 16. Peta Penutup Lahan Lokasi Penelitian di Desa Hargotirto

Nilai kerentanan inilah yang kemudian diinterpolasi sehingga akan menghasilkan zonasi kerentanan longsor di daerah penelitian. Berdasarkan interpolasi data nilai kerentanan longsor diperoleh empat tingkat zona kerentanan longsor, yaitu rendah, sedang, tinggi, dan sangat tinggi (Gambar 19).

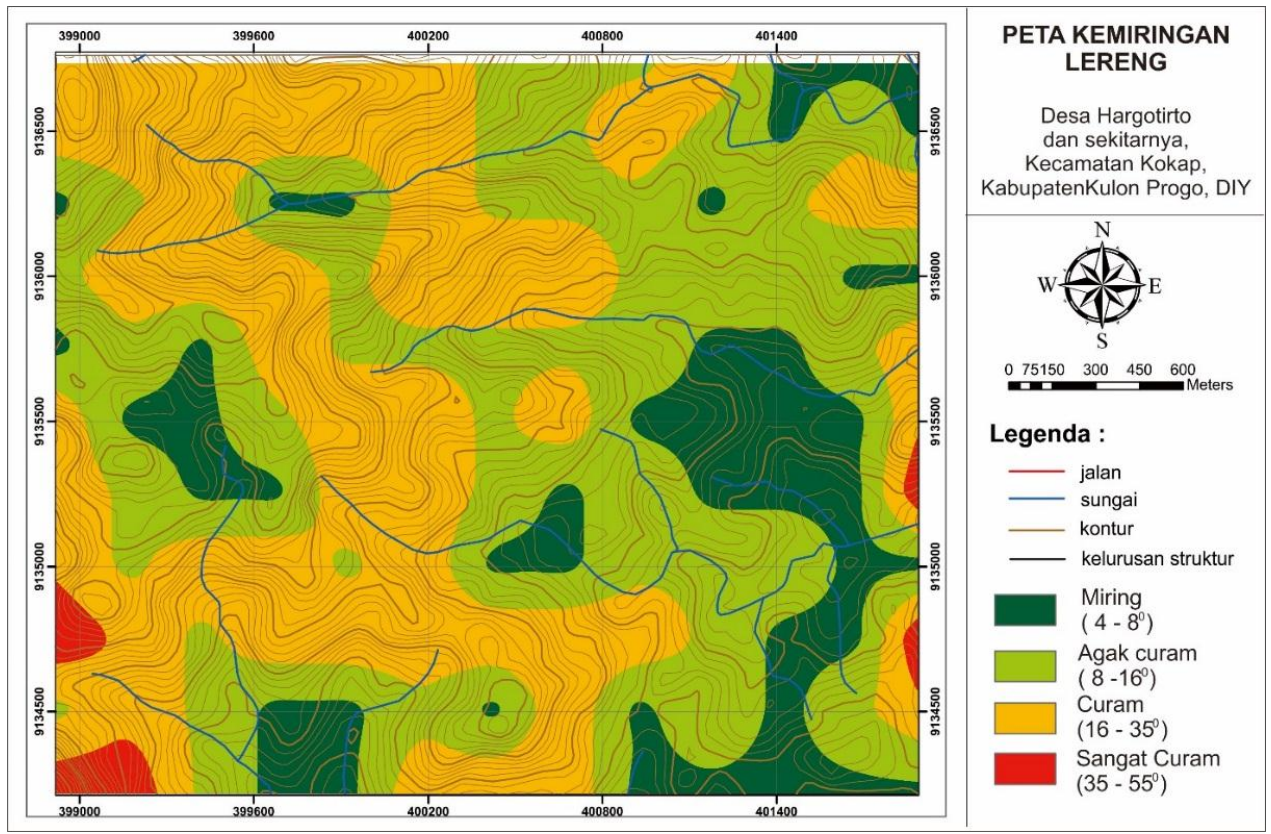

Sumber: Husna (2018)

Gambar 17 Peta Kemiringan Lereng Daerah Penelitian di Desa Hargotirto 


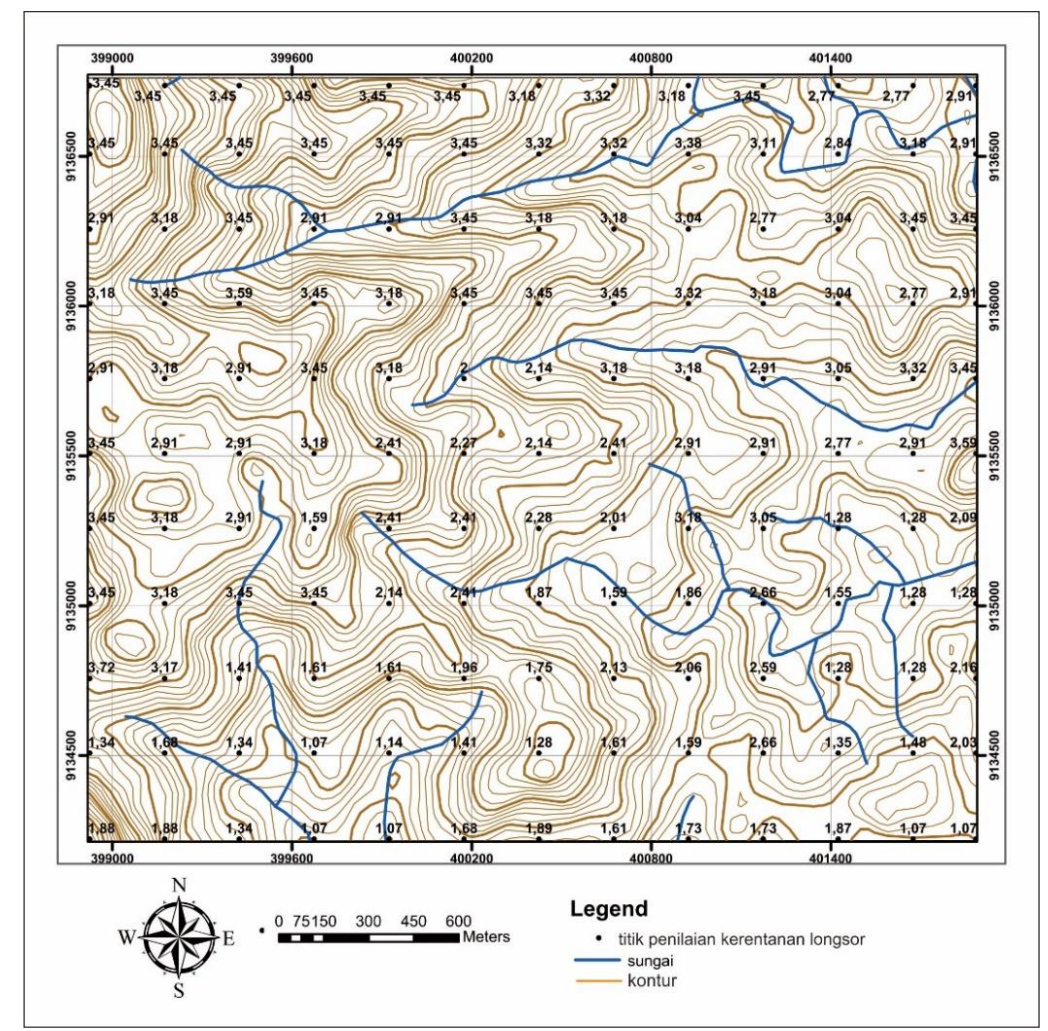

Sumber: Husna (2018)

Gambar 18 Titik dan Nilai Tingkat Kerentanan Longsor Daerah Penelitian Di Desa Hargotirto

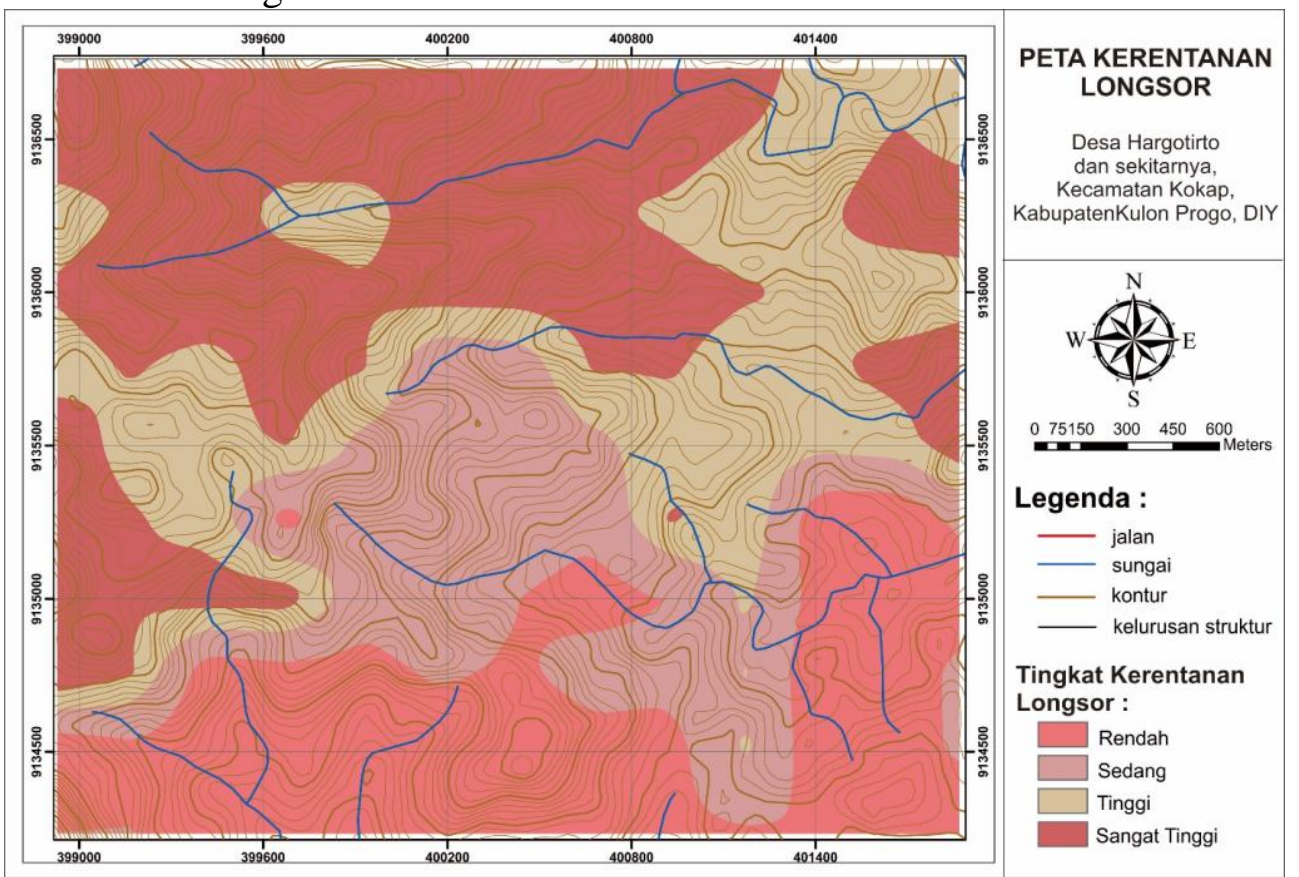

Sumber: Husna (2018)

Gambar 19 Peta Kerentanan Longsor Daerah Penelitian di Desa Hargotirto

Zona kerentanan tinggi mendominasi dan melingkupi 35\%. Zona ini berada di bagian tengah dan timur laut daerah penelitian yang lahannya diperuntukan sebagai pemukiman. 


\section{SIMPULAN}

Satuan litologi yang menyusun daerah penelitian adalah satuan andesit dan satuan diorit porfiri dengan kelurusan struktur barat-timur. Sebagian besar batuan penyusun daerah penelitian telah mengalami alterasi menjadi alterasi argilik dan propilitik dengan intensitas rendah hingga tinggi. Hal itu dicirikan oleh kehadiran mineral lempung berjenis kaolinit, smektit, dan klorit yang mempunyai sifat impermeabel sehingga sangat mudah berfungsi sebagai zona bidang gelincir.

Sebaran struktur massa batuan kelompok disturbed-disintegrated dan blocky-very blocky yang mendominasi daerah penelitian menyebabkan kondisi batuan menjadi tidak stabil. Jenis penutup lahan didominasi oleh vegetasi tinggi dan relatif tersebar merata di daerah penelitian, sedangkan pemukiman lebih terkonsentrasi di bagian timur laut. Kemiringan lereng yang agak curam $\left(8-16^{\circ}\right)$ berada di bagian timur dan timur laut daerah penelitian yang pemanfaatannya didominasi sebagai pemukiman. Berdasarkan integrasi data-data dari penelitian ini, zona kerentanan longsor di daerah penelitian dapat dibagi menjadi empat, yaitu rendah, sedang, tinggi, dan sangat tinggi. Zona kerentanan longsor tinggi mendominasi dan melingkupi 35\% serta berada di bagian tengah dan timur laut dari daerah penelitian yang lahannya peruntukan sebagai pemukiman. Penduduk yang bermukim di daerah penelitian disarankan untuk selalu waspada terhadap kemungkinan terjadinya longsor karena termasuk dalam zona kerawanan longsor sangat tinggi dan tinggi.

Saran untuk penelitian selanjutnya adalah sebaiknya sampel geokimia yang digunakan lebih banyak agar lebih representatif dalam mengidentifikasi tipe dan intesitas alterasi. Selain itu, dapat dilakukan penentuan zonasi longsor menggunakan metode yang lain dengan parameter yang lebih banyak. Bagi penduduk yang bermukim pada zona rawan longsor sangat tinggi dan tinggi diharapkan untuk selalu waspada dan berhati-hati karena longsor bisa terjadi sewaktuwaktu.

\section{DAFTAR PUSTAKA}

Badan Nasional Penanggulangan Bencana. (2017). Data dan Informasi Bencana Indonesia. Retrieved from http://dibi.bnpb.go.id

Badan Penanggulaangan Bencana Daerah Provinsi DIY. (2017). Peta Bencana Tanah Longsor. Retrieved from http://bpbd.jogjaprov.go.id

Barianto, D. H., Harijoko, A., \& Watanabe, K. (2009). The Tertiary Volcanic Rocks Distribution In Yogyakarta And Its Vicinity, Indonesia. Earth Science International Conference Journal, Manila, pp. 5.

Bemmelen, R. W. V. (1949). The Geology of Indonesia 1. Amsterdam: Government Printing Office The Hauge.

Direktorat Jendral Penataaan Ruang. (2007). Pedoman Penataan Ruang di Kawasan Rawan Bencana Longsor. Departemen Pekerjaan Umum. 
Harjanto, A. (2010). Alterasi Akibat Proses Hidrotermal di Daerah Kulon Progo dan Sekitarnya Daerah Istimewa Yogyakarta. JIK TekMin, September-Desember 2010, Vol. 23(3).

Harjanto, A. (2011) Petrologi dan Geokimia Batuan Volkanik di Daerah Kulon Progo dan Sekitarnya Daerah Istimewa Yogyakarta. Jurnal Ilmiah MTG, Vol.4, No.1.

Husna, H. Z. K. (2018). Geologi dan Alterasi Hidrotermal untuk Penentuan Zona Kerentanan Longsor di Desa Hargotirto dan Sekitarnya, Kecamatan Kokap, Kabupaten Kulon Progo, Provinsi Daerah Istimewa Yogyakarta. Skripsi. Departemen Teknik Geologi, Fakultas Teknik, Universitas Gadjah Mada (unpublished)

Large, R., R., Gemmel, J. B., Paulic H., \& Houston, D. L. (2001). The Alteration Box Plot: A Simple Approach to Understanding the Relationship between Alteration Mineralogy and Lithogeochemistry Associated with Volcanic-Hosted Massive Sulfide Deposits. Economic Geology, Vol. 96, 957-971.

Pramumijoyo, P. (2017). Geologi, Geokimia, dan Karakteristik Fluida Hidrotermal pada Endaparan Epitermal Sulfidasi Rendah di Daerah Sangon, Kokap, Daerah Istimewa Yogyakarta. Yogyakarta: Universitas Gadjah Mada Press.

Rahardjo, Sukandarrumidi, \& Rosidi. (1995). Peta Geologi Lembar Yogyakarta Jawa. Pusat Penelitian dan Pengembangan Geologi.

Saaty, T.L. (2008). Decision Making with the Analytic Hierarchy Process. Int, J. Services Sciences, I, 83-97. 